\title{
Export Diversification Model - a Strategic View for Economic Development with reference to Pakistan
}

\author{
${ }^{1}$ Dr. A. R. Zaki, ${ }^{2}$ Dr. Muhammad Asim \\ ${ }^{1}$ Chairman, Karachi University Business School University of Karachi University Road, Karachi-75270, \\ Pakistan \\ ${ }^{2}$ Assistant Professor Karachi University Business School University of Karachi University Road, Karachi- \\ 75270, Pakistan
}

\begin{abstract}
The objective of this study is to examine the causes of the falling trend of Pakistan exports and to suggest measures for diversification of export in terms of countries and commodities.

During the research study it came to light that Pakistan's export suffered lack of diversification both on account of countries and commodities. According to Government's survey Pakistan's export is concentrated about $62 \%$ on cotton related products (refer Table 1 \& Table 2 ).

This review has helped us in a realistic assessment of exports and projection of views that may result in export enhancement and diversification. Towards this effort, diversification strategy model has been suggested and it is expected that the strategy when implemented would not only cause least constraints at different stages of export diversification but would also facilitate the large scale promotion of export.
\end{abstract}

Keyword: Diversification Strategy, Social development Agricultural product, Export earnings, Concentrated structural transformation.

\section{Introduction:}

The progress and prosperity of any country depends upon several factors such as scientific development, social development but the pivotal role is played by the economic development which has the potential to positively revolutionize the whole system of progress and lead the country towards the goal of success and economic prosperity.

In early period Pakistan's economy was based on agriculture which played an important role in the general export earnings. Food exports account for 17 per cent of all exports of the country. More importantly, fifty three percent of Pakistan's total exports comprise textile products which use cotton as raw material. The share of raw cotton exports is small at 1.2 per cent.

Among some of the factors responsible for retarding the economic development, the main factor or reason is that Pakistan has not made any progress worth mentioning in the field of export.

The important fact is that the value of the exports from Pakistan has not caught up with the value of its import. The prospects for the rapid transformation of the economy of Pakistan seem to be to redistribute the real resources in both the industrial and agricultural sectors for the production of value added items specially those which can be exported. The transition in economic management hinges upon adoption of best international practices as in vogue in countries like South Korea and Taiwan. A further component of this new strategy would call for a production of trained labor force including the high level personnel specialized in latest skills.

The study focuses itself on measures required for "Export Diversification". Without diversification and continuing on the same pattern, Pakistan cannot sustain its economy for long. The logic is further augmented by the fact that Pakistan's yearly export has always lagged behind its imports. In fact the trade deficit has widened over the years. Thus there is an immediate need to increase exports in a manner that it is able to exceed imports and the only way that this objective can be achieved is through both commodity and country diversification. The study as such aims to explore such ways and means whereby export diversification could be achieved. This would mean addition of a larger number of products and countries to represent major contributes in the total export value in the not so far distant a future. This should be seen in the context of WTO after the advent of which Pakistan's current exports would be fiercely attacked by other third world countries who would try to push their products into newer territories to sustain themselves and to be able to obtain or maintain a positive trade balance, Pakistan needs to shift the pressure on cotton related items to other commodities because even the countries which are major trade partners are importing cotton related items to a large extent. This means that commodity diversification needs to be given first priority.

\section{Methodology and Application of Model}

The study of hypothesis is assumed that the export of Pakistan is concentrated on a few commodities and countries. The study also assumes that the country has not been able to shower positive growth in its revenue in the last few decades because of this lack of diversification in the country's export. 
Having explored these issues the study proposes a model for export diversification of the country. The methodology for this study is designed to develop a model for diversification.

Quantitative data as a secondary source has been used to analyze the export, Foreign Trade Statistics of Pakistan which is the prime source of key data of export. referred.

Statistical year book which is the publication of Federal Bureau of Statistics department has also

The model applied for trade data analysis is basically the model of dominance based on variance on the "Mean of the squared deviation about the mean" or least square or variance. This model is applied to analyze the export pattern/trend whether concentrated or diversified.

$$
\sigma^{2}=\sum d^{2} / N=\sum(x-\mu)^{2} / N
$$

Where ' $\mathrm{x}$ ' is the real value, expressed in percentage and arranged in descending order, and $\mu$ is the theoretical mean. For single commodity dominance $\mu$ is taken to be $100 \%$ associated with the top ranking value of ' $x$ '. Similarly $50 \%, 33.33 \%, 25 \%, 20 \% \ldots$ are associated with first two, three, four and five values respectively and so on. For single commodity dominance and for identifying other commodity combinations following procedure is adopted:

$\sigma_{1}^{2}=\sum(\mathrm{x}-\mu)^{2} / \mathrm{N}=\left(\mathrm{x}_{1}-100\right)^{2}+\left(\mathrm{x}_{2}+0\right)^{2}+\left(\mathrm{x}_{3}+0\right)^{2}+\ldots \ldots+\left(\mathrm{x}_{\mathrm{n}}+0\right)^{2} / \mathrm{N}$

$\sigma_{2}^{2}=\sum(\mathrm{x}-\mu)^{2} / \mathrm{N}=\left(\mathrm{x}_{1}-50\right)^{2}+\left(\mathrm{x}_{2}+50\right)^{2}+\left(\mathrm{x}_{3}+0\right)^{2}+\ldots \ldots+\left(\mathrm{x}_{\mathrm{n}}+0\right)^{2} / \mathrm{N}$

$\sigma_{3}{ }^{2}=\sum(\mathrm{x}-\mu)^{2} / \mathrm{N}=\left(\mathrm{x}_{1}-33.33\right)^{2}+\left(\mathrm{x}_{2}+33.33\right)^{2}+\left(\mathrm{x}_{3}+33.33\right)^{2}+\left(\mathrm{x}_{4}+0\right)^{2}+\left(\mathrm{x}_{5}+0\right)^{2}+\ldots+\left(\mathrm{x}_{\mathrm{n}}+0\right)^{2} / \mathrm{N}$

$\sigma_{4}{ }^{2}=\sum(\mathrm{x}-\mu)^{2} / \mathrm{N}=\left(\mathrm{x}_{1}-25\right)^{2}+\left(\mathrm{x}_{2}+25\right)^{2}+\left(\mathrm{x}_{3}+25\right)^{2}+\left(\mathrm{x}_{4}+25\right)^{2}+\left(\mathrm{x}_{5}+0\right)^{2}+\left(\mathrm{x}_{6}+0\right)^{2}+\ldots+\left(\mathrm{x}_{\mathrm{n}}+0\right)^{2} / \mathrm{N}$

Expert data is divided into two groups termed as major and minor (refer Table 1 and Table 2).

The qualitative data were collected through questionnaire from Entrepreneurs and exporters for their perception views and suggestions regarding the export situation in Pakistan. This primary information was analyzed in terms of numbers representing various aspects of trade in Pakistan. Through the above model it has been proved that Pakistan's export trade is concentrated and need diversification.

Analysis \& Application of Trade Data in terms of Countries Analysis of Export Data in Terms of Countries for the Year $(2000-2001)$

Table 1

\begin{tabular}{|c|c|c|c|c|c|}
\hline & & $\begin{array}{l}\text { Value in Pak } \\
\text { Rupees (in } \\
\text { thousands) }\end{array}$ & $\begin{array}{l}\text { Percentage of } \\
\text { total export }\end{array}$ & & $\begin{array}{c}\text { U.S. \$ } \\
\text { (in millions) }\end{array}$ \\
\hline \multicolumn{2}{|r|}{ Total } & 539070143 & & & 8984.5024 \\
\hline \multicolumn{2}{|r|}{ Major Countries 16} & 402641616 & $74.69 \%$ & & 6710.6936 \\
\hline \multicolumn{2}{|r|}{ Minor Countries 181} & 136428527 & $25.31 \%$ & & 2273.8088 \\
\hline \multicolumn{6}{|c|}{ MAJOR } \\
\hline S. No. & Country & Value & $\begin{array}{c}\text { Percentage of } \\
\text { total export }\end{array}$ & Variance & $\begin{array}{c}\text { U.S. \$ } \\
\text { (in millions) }\end{array}$ \\
\hline 1 & USA & $131,263,468$ & 24.34997926 & 5949.5961 & 3187.7244 \\
\hline 2 & DUBAI & $36,197,281$ & 6.714762721 & 2713.1178 & 603.2880 \\
\hline 3 & UNITED KINGDOM & $33,768,686$ & 6.264247137 & 1663.9083 & 562.8114 \\
\hline 4 & HONG KONG & $29,518,343$ & 5.47578889 & 1179.3531 & 491.9724 \\
\hline 5 & FED REP OF GERMANY & $28,977,211$ & 5.375406406 & 892.3846 & 482.9535 \\
\hline 6 & CHINA & $17,772,724$ & 3.296922345 & 770.6786 & 296.2121 \\
\hline 7 & SOUTH KOREA & $16,342,800$ & 3.031664842 & 690.2502 & 272.3800 \\
\hline 8 & SAUDI ARABIA & $16,060,234$ & 2.979247545 & 632.3915 & 267.6706 \\
\hline 9 & FRANCE & $15,533,858$ & 2.881602367 & 589.0679 & 258.8976 \\
\hline 10 & NETHERLANDS & $13,641,348$ & 2.530533026 & 561.5889 & 227.3558 \\
\hline 11 & ITALY & $13,548,515$ & 2.513312076 & 539.2842 & 225.8086 \\
\hline 12 & JAPAN & $11,246,104$ & 2.086204207 & 527.7143 & 187.4351 \\
\hline 13 & CANADA & $10,658,493$ & 1.977199654 & 519.807 & 177.6416 \\
\hline 14 & BELGIUM & $10,247,306$ & 1.900922567 & 514.0315 & 170.7884 \\
\hline 15 & SPAIN & $9,512,016$ & 1.764522878 & 511.207 & 158.5336 \\
\hline 16 & AFGHANISTAN & $8,353,229$ & 1.54956254 & 510.9435 & 139.2205 \\
\hline
\end{tabular}


TABLE 2

Analysis of Export Data (In Terms of Commodities) For the year 2000-2001

By Thomas Model Application $\sigma^{2}=\frac{\sum d^{2}}{N}=\frac{\sum(x-\mu)^{2}}{N}$

\begin{tabular}{|c|l|c|c|c|c|}
\hline \multicolumn{5}{|c|}{ MAJOR } \\
\hline $\begin{array}{c}\text { S. } \\
\text { No. }\end{array}$ & \multicolumn{1}{|c|}{ Commodities } & \multicolumn{1}{|c|}{$\begin{array}{c}\text { Value in Pak } \\
\text { Rupees }\end{array}$} & $\begin{array}{c}\text { Percentage of } \\
\text { Total Export }\end{array}$ & Variance & $\begin{array}{c}\text { U.S. \$ } \\
\text { (in millions) }\end{array}$ \\
\hline 1 & $\begin{array}{l}\text { Cotton (gauze, terry towelling, } \\
\text { unbleached, mill made, handloom, } \\
\text { fabrics, woven fabrics, products, } \\
\text { curtains towel ) }\end{array}$ & 78206189.00 & 14.41 & 7895.38 & 1303.4365 \\
\hline 2 & Garments for men / boys & 75083746.00 & 13.83 & 2952.90 & 1251.3958 \\
\hline 3 & $\begin{array}{l}\text { Yarn (cotton, comb, uncomb, } \\
\text { synthetic, single, filament, silk) }\end{array}$ & 67084137.00 & 12.36 & 1403.25 & 1118.0690 \\
\hline 4 & $\begin{array}{l}\text { Bedlinen (blankets, bedcover, pillow } \\
\text { cover, khes of cotton, fitedsheet, quilts } \\
\text { of cotton) }\end{array}$ & 44434466.00 & 8.19 & 837.63 & 740.5744 \\
\hline 5 & $\begin{array}{l}\text { Fabrics (wool, high tenacity, synthetic } \\
\text { textile, suiting synthetic, noil silk, silk, } \\
\text { jute, terry towelling, pile, knitted, } \\
\text { woven) }\end{array}$ & 36820779.00 & 6.78 & 554.12 & 613.6797 \\
\hline 6 & Wheat, rice, barley, maiz, jowar, bajra & 31594880.00 & 5.82 & 397.45 & 526.5813 \\
\hline 7 & Garment / clothing accessories & 25986654.00 & 4.79 & 314.24 & 433.1109 \\
\hline 8 & Garments for women & 17228366.00 & 3.17 & 293.04 & 287.1394 \\
\hline 9 & Carpets, rugs, durees & 17016523.00 & 3.13 & 277.05 & 283.6087 \\
\hline 10 & Sports goods & 15918863.00 & 2.93 & 268.41 & 265.3144 \\
\hline 11 & Leather \& its product & 14464549.00 & 2.66 & 266.13 & 241.0758 \\
\hline
\end{tabular}

Theoretical Formations and Variable Description:

The suggested model Fig-1 incorporates four variables which are in turn reinforced by sub variables which elaborate the aforesaid objectives.

Fig - 1 : DIVERSIFICATION MODEL

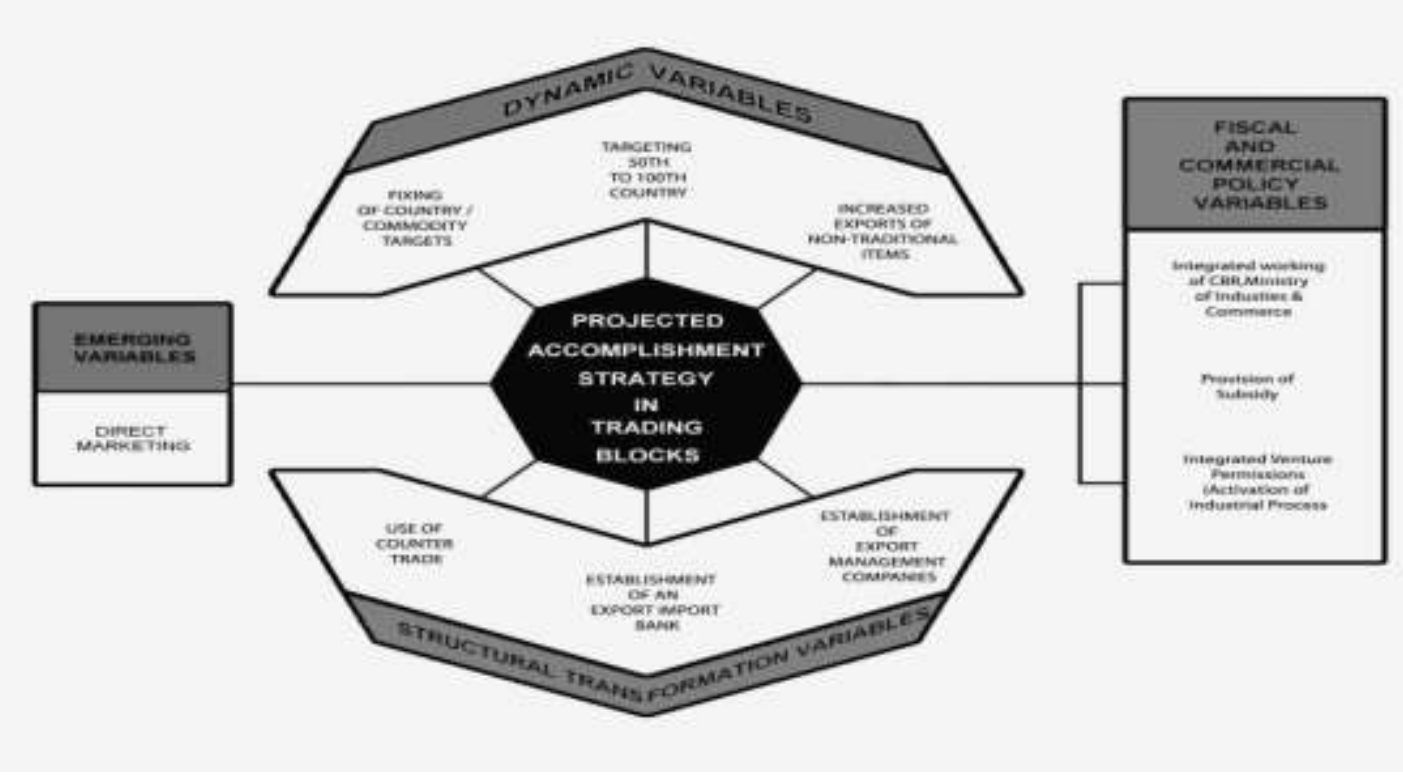

1. Dynamic 2. Emerging 3. Structural Transformation 4. Fiscal Commercial Policy 
The above core factors notify necessary measures required for obtaining the desired results in the shortest possible time as well as in the long run.

The strategy when implemented would cause least constraints at different stages of export diversification.

$\mathrm{E}_{\mathrm{p}}=$ Export Promotion

$$
E_{p}=f\left(D_{v}, E_{v}, S T_{v}, F_{v}\right)
$$

$\mathrm{D}_{\mathrm{v}}=$ Dynamic Variables

$\mathrm{E}_{\mathrm{v}}=$ Emerging Variables

$\mathrm{ST}_{\mathrm{v}}=$ Structural Transformation Variables

$\mathrm{FC}_{\mathrm{v}}=$ Fiscal and Commercial policy variables

$\mathrm{F}=$ factor

The above four factors represent an integrated policy package period. However, each factor would require a time frame to smooth accomplishment of the objective. Thus, projection covering a period (2000-01), yields export figures reposted for future projection.

This shows that the model provides a realistic appraisal of the possible country commodity penetration that is to say that incase of COUNTRIES, of export, the figure comes to US dollars 21 billion whereas, for the COMMODITIES exported, the value figures out to be US dollars 20 billion which indicates that the 'Country' and 'Commodity' aggregates are matching.

The details of each core factor forming a past of the model and its modalities are given below:

\section{Dynamic Variables}

In the first place, the diversification model lays emphasis on certain factors which will help result in the enhancement of the present export level to a much higher level by concentrating attention on areas where the present penetration level is weak. These factors will have a link with the model representing preliminary areas of attack. The thrust factors carry a weightage related to the existing export areas and do not require the establishment of new entities or institutions to support the need for export enhancement or diversification. The only need in this context is to emphasize the removal of bottlenecks snags that have hampered expansion of export.

These factors have been categorized as the basic criteria for export diversification. An attempt in this regard by the policy makers will not require any complicated maneuvering or manipulation to bring about a change in the current export scenario. The respective factors in order of priority as to their resultant effect are detailed below and provide a bird's eye-view of the impact they will have, if implemented on export diversification.

It should be seen that the model relates all the factors to one basic ingredient which is to obtain greater market penetration in the member countries of various trading blocks. There are a total of 37 countries Federation of Pakistan (2002) which are linked up together as world's economic regions or blocks, and the total market size of these economic regions represents the major portion of the total world trade Federation of Pakistan (2002). As such, if Pakistan is able to have greater thrust in these markets both in terms of obtaining an increased per-country volume coupled with achieving diversified commodity penetration, the export picture in future years will show a marked change as compared to what was in recent years. The respective thrust factors should be seen in the above context and their effect towards achieving export diversification analyzed in direct relation to the above point of view.

\section{1(a). Fixing of Country \& Commodity Target}

For the purpose of export diversification, it becomes necessary to start the homework by fixing country/commodity targets in line with current export levels and with the market capacity of each country or commodity. Talking about country export targets, the minimum export level per country should be fixed at US $\$ 100$ million. This will be valid for countries which are currently generating an export volume of US $\$ 20$ or 25 million or more. Thus each of the fifteen countries starting from Denmark and culminating at Austria should be able to provide an export volume of \$120 million in the year 2008.

Table 3 shows the actual volume obtained in 2000-01 as well as the projected volume for 2008 for the first 50 countries. The projected volume for each country has a relationship with the current export level and the available potential. It can be seen that only the first sixteen countries classed as major can provide an export volume of US $\$ 13.2$ billion if targets are set and projected volume obtained.

Similar to the selection of first 50 countries the first 50 commodities have been chosen to cross-match the country targets with the commodity targets. The analysis shows that those commodities which fetched a value figure of US $\$ 8$ billion in 2000-2001 can, if aggressively pursued to a value figure of US $\$ 20$ billion in 2008. 
The targets fixed for individual commodities have been arrived at by looking at their export levels and can be termed as realistic based on a reasonable annual growth rate.

While fixing individual commodity targets a relationship should first be established as to what percentage of the total world export these commodities can generate. It becomes clear, when viewed from this perspective, that Pakistan's current export level represents infinitesimal world percentages. A case in point is the total world trade figure of US $\$ 4000$ billion obtained in 1994 Hill. (2002). In contrast Pakistan's total export/import trade 2000-01 stood at only US $\$ 20$ billion which is very small in the context of world trade.

Commodities like bed linen, rice, and fabric and clothing accessories have the potential to enhance the value of US $\$ 1$ billion. There are additional export items such as garments for women, carpets and rugs, sports goods and leather goods which currently contributing US\$ 3 billion could potentially produce another US\$ 10 billion exports. It will become necessary to carry out a study of international statistics for respective countries and commodities. Based on this information the exporters and the Pakistan Trade Authority should endeavor to attain the targets set also to be examined will be those countries which are exporting large volumes of exports by countries and commodities.

The targets set for major countries among which the US is on the top of the exports list show projections for 2008 in relation to actual export figures for 2000-01 (Thomas Model Table).

The contribution of these major countries amounted to US $\$ 6.7$ billion in 2000-01 whereas the projected figure gives a total achieve value of US $\$ 13.12$ billion (Thomas Model Table). This projection is considered realistic in view of the economic size, absorptive capacity and typical product requirements of these countries, even countries like Indonesia, Bangladesh, Turkey and Portugal touched an export revenue around US $\$ 100$ million in $2000-01$. The projection for these countries for the year 2008 has also been made in relation to this data.

It will be seen that the projections for the year 2008 reflect the current export level coupled with the absorptive capacity of each country in relation to the product mix being currently exported.

On a similar footing, if the list of commodities as given in Table 4 is examined, it is found that 11 major commodities account for an export revenue of US\$ 7.25 billion in 2000-01 and when projected for 2008 the same commodities provide a value total which stands at US $\$ 13.8$ billion. Another four commodities provided an export revenue of US \$121 million to US \$190 million each in 2000-01. This is targeted at US $\$ 1.18$ billion for 2008. Commodities contributing US $\$ 60$ million to US $\$ 90$ million adding upto 9 and their projections provide a value figure of US $\$ 1.2$ billion.

The noteworthy point in the above analysis is the cross-matching of commodity export figures with country export figures. This cross-match is visible when it is seen that the projected export figures for 16 major countries account for US $\$ 13.2$ billion whereas 11 major commodities provide a value yield of US $\$ 13.8$ billion. In this context, it can simply be argued that both the country and the commodity targets are aligned in a manner that the total value discrepancy is only nearly statistical.

Table 3 has been reinforced now with total import figures of the countries chosen for data projection into the year 2008. Certain countries have been dropped and new ones substituted on the basis of the absorptive capacity of these countries. The total imports for each country when related to projected level stands to justify the author's contention that projections made are truly in line with what they should in reality be. Just as a case the projected export level for USA if attained would only represent $0.26 \%$ of the total world imports of that country. A similar parity exists in case of the other listed countries obviously a fractional substitution of various countries total world imports has been aimed at and the figures projected should be considered as the minimal export level that Pakistan should be able to achieve at any cost.

TABLE 3

COUNTRY TARGET

\begin{tabular}{|c|l|c|c|c|}
\hline S. NO. & NAME & $\begin{array}{c}\text { Actual Export } \\
\mathbf{2 0 0 0 - 2 0 0 1} \\
\text { (Million dollars) }\end{array}$ & $\begin{array}{c}\text { Projected Export } \\
\mathbf{2 0 0 8} \\
\text { (Million dollars) }\end{array}$ & $\begin{array}{c}\text { Total Country } \\
\text { Imports } \\
\mathbf{2 0 0 6} \\
\text { (Million dollars) }\end{array}$ \\
\hline 1 & USA & 3,187 & 4,800 & 1919.4 \\
\hline 2 & Dubai (UAE) & 603 & 1,200 & 97.8 \\
\hline 3 & UK & 563 & 1,200 & 619.4 \\
\hline 4 & Hong Kong & 492 & 720 & 335.8 \\
\hline 5 & Germany & 483 & 720 & 908.6 \\
\hline 6 & China & 296 & 480 & 791.5 \\
\hline 7 & South Korea & 272 & 480 & 309.4 \\
\hline 8 & Saudi Arabia & 267 & 720 & 66.3 \\
\hline 9 & France & 259 & 480 & 534.9 \\
\hline
\end{tabular}

www.iosrjournals.org 
Export Diversification Model - A Strategic View for Economic Development with reference to

\begin{tabular}{|c|c|c|c|c|}
\hline 10 & Netherlands & 227 & 480 & 416.4 \\
\hline 11 & Italy & 226 & 420 & 437.4 \\
\hline 12 & Japan & 187 & 360 & 579.6 \\
\hline 13 & Canada & 178 & 360 & 357.7 \\
\hline 14 & Belgium & 171 & 360 & 353.7 \\
\hline 15 & Spain & 156 & 360 & 316.4 \\
\hline 16 & Hungary & 8 & 120 & 77.0 \\
\hline 17 & Indonesia & 131 & 240 & 80.3 \\
\hline 18 & Ireland & 7 & 120 & 72.8 \\
\hline 19 & Australia & 101 & 360 & 139.3 \\
\hline 20 & Turkey & 98 & 240 & 138.3 \\
\hline 21 & Portugal & 86 & 180 & 66.6 \\
\hline 22 & Brazil & 7 & 120 & 95.9 \\
\hline 23 & South Africa & 68 & 240 & 77.3 \\
\hline 24 & Thailand & 62 & 180 & 128.6 \\
\hline 25 & Sweden & 60 & 180 & 126.7 \\
\hline 26 & India & 59 & 240 & 174.8 \\
\hline 27 & Malaysia & 54 & 360 & 131.2 \\
\hline 28 & Poland & 7 & 120 & 126.0 \\
\hline 29 & Singapore & 48 & 120 & 128.7 \\
\hline 30 & Romania & 3 & 120 & 51.1 \\
\hline 31 & Greece & 45 & 180 & 63.2 \\
\hline 32 & Austria & 17.8 & 180 & 140.3 \\
\hline 33 & Iran & 23.4 & 180 & 51.1 \\
\hline 34 & Vietnam & 43 & 120 & 44.4 \\
\hline 35 & Chile & 40 & 120 & 38.4 \\
\hline 36 & Denmark & 40 & 120 & 80.3 \\
\hline 37 & Qatar & 36 & 120 & \\
\hline 38 & Philippines & 35 & 120 & 51.5 \\
\hline 39 & Mauritius & 32 & 120 & \\
\hline 40 & Argentina & 28 & 120 & 34.2 \\
\hline 41 & Venezuela & 16.4 & 120 & 33.6 \\
\hline 42 & Norway & 27 & 120 & 64.1 \\
\hline 43 & New Zealand & 25 & 120 & \\
\hline 44 & Mexico & 24 & 120 & 268.2 \\
\hline 45 & Switzerland & 24 & 120 & 88.9 \\
\hline 46 & Iran & 24 & 120 & 51.1 \\
\hline 47 & Kenya & 22 & 360 & \\
\hline 48 & Tanzania & 20 & 120 & \\
\hline 49 & Vietnam & 20 & 120 & 38.4 \\
\hline \multirow[t]{2}{*}{50} & Austria & 19 & 120 & 140.3 \\
\hline & TOTAL & 8883 & 21088 & \\
\hline
\end{tabular}

Source : http://www.intracen.org/tradstat/sitc3-3d

TABLE 4

COMMODITY TARGET

\begin{tabular}{|c|l|c|c|}
\hline S. No. & \multicolumn{1}{|c|}{ COMMODITY } & $\begin{array}{c}\text { Actual Export } \\
\mathbf{2 0 0 0 - 2 0 0 1} \\
\text { (Million dollars) }\end{array}$ & $\begin{array}{c}\text { Projected Export } \\
\text { 2008 } \\
\text { (Million dollars) }\end{array}$ \\
\hline 1 & Gauze Terry Toweling & 1,303 & 2,400 \\
\hline 2 & Garments for men & 1,251 & 2,400 \\
\hline 3 & Yarn & 1,128 & 1,800 \\
\hline 4 & Bed linen & 741 & 1,200 \\
\hline 5 & Fabrics & 613 & 1,200 \\
\hline 6 & Wheat and rice & 527 & 1,200 \\
\hline 7 & Clothing Accessories & 433 & 1,200 \\
\hline
\end{tabular}




\begin{tabular}{|c|c|c|c|}
\hline 8 & Garments for women & 287 & 600 \\
\hline 9 & Carpets and rugs & 284 & 600 \\
\hline 10 & Sports goods & 265 & 600 \\
\hline 11 & Leather products & 241 & 600 \\
\hline 12 & Cotton waste & 188 & 360 \\
\hline 13 & Fuel petroleum & 181 & 360 \\
\hline 14 & Cleaning clothes & 143 & 300 \\
\hline 15 & Dental instruments & 122 & 300 \\
\hline 16 & Parts of garments & 93 & 180 \\
\hline 17 & Fruit juices & 77 & 180 \\
\hline 18 & Shrimps and lobsters & 73 & 180 \\
\hline 19 & Camping goods & 69 & 180 \\
\hline 20 & Mops and mats & 64 & 120 \\
\hline 21 & Acids and bases & 64 & 120 \\
\hline 22 & Fish items & 63 & 120 \\
\hline 23 & Fresh fruits & 66 & 120 \\
\hline 24 & Table covers & 42 & 90 \\
\hline 25 & Plastic material & 41 & 90 \\
\hline 26 & Dried fruits & 41 & 90 \\
\hline 27 & Medicines & 38 & 72 \\
\hline 28 & Footwear & 37 & 72 \\
\hline 29 & Babies' garments & 35 & 72 \\
\hline 30 & Jaribooti (herbs) & 31 & 72 \\
\hline 31 & Oil seeds & 31 & 72 \\
\hline 32 & Bakery products & 30 & 72 \\
\hline 33 & Imitation jewelry & 27 & 72 \\
\hline 34 & Cutlery/brass/ware & 26 & 72 \\
\hline 35 & Vegetable beans & 23 & 72 \\
\hline 36 & Vegetable fats & 22 & 60 \\
\hline 37 & Electronic apparatus & 22 & 60 \\
\hline 38 & Vegetable & 21 & 60 \\
\hline 39 & Bones and horns & 16 & 36 \\
\hline 40 & Ship stores & 15 & 36 \\
\hline 41 & Grind stones & 15 & 36 \\
\hline 42 & Safety matches & 15 & 36 \\
\hline 43 & Tobacco & 15 & 36 \\
\hline 44 & Confectionery items & 14 & 36 \\
\hline 45 & Wall clocks & 14 & 36 \\
\hline 46 & Sewing machines & 12 & 24 \\
\hline 47 & Waste and ores & 10 & 24 \\
\hline 48 & Footwear parts & 9 & 24 \\
\hline 49 & Urea & 8 & 24 \\
\hline \multirow[t]{2}{*}{50} & Starches & 8 & 24 \\
\hline & Total & 8,894 & 19,798 \\
\hline
\end{tabular}

Source : http://www.intracen.org/tradstat/sitc3-3d

1(b). Increased Export of Non-Traditional Items

A total of 14 non-traditional items have been identified among the list of a total of 129 commodities (refer Table 5). The total yield in 2000-2001 from these non-traditional items works out at US \$48 million. The projections for 2008 for these commodities yield a value figure of US $\$ 0.5$ billion. All these commodities represent items where the domestic production can either be brought to higher levels or even at the present moment is far in excess of the domestic consumption requirements. In case Pakistan is able to penetrate both the existing and new markets with these commodities, a valuable addition to total export volume will emerge. Items like tractor parts, motorcycle parts, articles of aluminum, ceramic sanitary fixture and cotton thread are being produced according to international standard and their export enhancement will serve to achieve the desired export diversification. This is related to the fact that Pakistan needs to exploit whatever avenue is available for exploitation and commodity penetration. 
The recently formed Export Development Authority will need to critically examine these export items and identify markets which could be candidates for achieving the projected individual commodity targets. Table 5 provides a picture of all the identified commodities along with 2000-2001 export figures and their projection for the year 2008. The table has been totally revised to delete double counting and project more appropriate levels for FY 2008.

TABLE 5

NON-TRADITIONAL ITEMS

\begin{tabular}{|c|l|c|c|}
\hline S. No. & \multicolumn{1}{|c|}{ Commodities } & $\begin{array}{c}\text { Actual Export } \\
\mathbf{2 0 0 0}-\mathbf{2 0 0 1} \\
\text { (Million dollars) }\end{array}$ & $\begin{array}{c}\text { Projected Export } \\
\mathbf{2 0 0 8} \\
\text { (Million dollars) }\end{array}$ \\
\hline 1 & Tractor parts & 5.00 & 60 \\
\hline 2 & Marble & 5.00 & 60 \\
\hline 3 & Musical instruments & 3.00 & 60 \\
\hline 4 & Wood products & 3.00 & 60 \\
\hline 5 & Insecticides & 3.00 & 60 \\
\hline 6 & Make-up articles & 3.00 & 60 \\
\hline 7 & Motorcycle parts & 2.00 & 30 \\
\hline 8 & Traveling bags & 2.00 & 30 \\
\hline 9 & Emerald/Ruby & 2.00 & 30 \\
\hline 10 & Articles of aluminum & 2.00 & 30 \\
\hline 11 & Ceramic sanitary fixtures & 0.9 & 10 \\
\hline 12 & Salts & 0.9 & 10 \\
\hline 13 & Cotton thread & 0.9 & 10 \\
\hline 14 & Roofing tiles & 0.9 & 10 \\
\hline & & $\mathbf{4 8}$ & $\mathbf{4 6 0}$ \\
\hline
\end{tabular}

\section{1(c). Targeting $50^{\text {th }}$ to $100^{\text {th }}$ Country}

The total exports recorded in 2000-2001 for countries representing $50^{\text {th }}$ to $100^{\text {th }}$ count in Table 2 stand at US \$414.58 million. This export volume averages at US\$ 5 million per country and shows inherent weaknesses in exports to these countries. As such projected into 2008 the value figure stands at 2.8 billion, which apparently shows very substantial jump in an 8 years period. However in order to diversify and expand the export volume it is inherent that this export target is achieved for the remaining 50 countries by TDAP for export revenue generation.

Table 6 shows the comparative picture of 2000-2001 actual viz-a-viz projections for 2008.

TABLE 6

Targeting $50^{\text {th }}$ to 100th Country

\begin{tabular}{|c|l|c|c|}
\hline S. No. & \multicolumn{1}{|c|}{ Country } & $\begin{array}{c}\text { Actual Export } \\
\mathbf{2 0 0 0 - 2 0 0 1} \\
\text { (Million Dollars) }\end{array}$ & $\begin{array}{c}\text { Projected Export } \\
\text { 2008 } \\
\text { (Million Dollars) }\end{array}$ \\
\hline 51 & VIET NAM & 19.5940 & 30 \\
\hline 52 & REPUBLIC OF BENIN & 18.5963 & 30 \\
\hline 53 & AUSTRIA & 17.8864 & 30 \\
\hline 54 & IRISH REPUBLIC & 16.8701 & 30 \\
\hline 55 & VENEZUELA & 16.4892 & 30 \\
\hline 56 & IRAQ & 16.0425 & 30 \\
\hline 57 & JORDAN & 15.5304 & 30 \\
\hline 58 & IVORY COAST & 14.9629 & 30 \\
\hline 59 & FINLAND & 14.6716 & 30 \\
\hline 60 & MOROCCO & 13.8904 & 20 \\
\hline 61 & MALAGASY & 12.7430 & 20 \\
\hline 62 & NIGER & 12.4923 & 20 \\
\hline 63 & REP OF THE CONGO & 10.7072 & 20 \\
\hline 64 & LEBANON & 10.2512 & 20 \\
\hline
\end{tabular}


Export Diversification Model - A Strategic View for Economic Development with reference to

\begin{tabular}{|l|l|c|c|}
65 & HONDURAS & 9.8623 & 20 \\
\hline 66 & TUNISIA & 9.7461 & 20 \\
\hline 67 & REPUBLIC OF UZBEKIST & 9.6405 & 20 \\
\hline 68 & GUATEMALA & 9.4479 & 20 \\
\hline 69 & REPUBLIC OF KAZAKHST & 9.3141 & 20 \\
\hline 70 & COLOMBIA & 9.1137 & 20 \\
\hline 71 & PANAMA & 8.9735 & 20 \\
\hline 72 & TOGO & 8.3379 & 20 \\
\hline 73 & CYPRUS & 7.9185 & 20 \\
\hline 74 & RUSSIAN FEDERATION & 7.9108 & 20 \\
\hline
\end{tabular}

\begin{tabular}{|c|c|c|c|}
\hline S. No. & Country & $\begin{array}{c}\text { Actual Export } \\
\text { 2000-2001 } \\
\text { (Million Dollars) }\end{array}$ & $\begin{array}{c}\text { Projected Export } \\
2008 \\
\text { (Million Dollars) } \\
\end{array}$ \\
\hline 75 & MAURITANIA & 7.6624 & 20 \\
\hline 76 & REPUBLIC OF ESTONIA & 6.9366 & 10 \\
\hline 77 & CZECH REPUBLICS & 6.5033 & 10 \\
\hline 78 & OCEANIA N.S. & 6.3033 & 10 \\
\hline 79 & ABU DHABI & 5.8552 & 10 \\
\hline 80 & SYRIA & 5.7713 & 10 \\
\hline 81 & EL-SALVADOR & 5.7583 & 10 \\
\hline 82 & SUDAN & 5.7544 & 10 \\
\hline 83 & DOMINICAN REPUBLIC & 5.7443 & 10 \\
\hline 84 & ZIMBABWE & 5.6836 & 10 \\
\hline 85 & CAMEROON & 5.6491 & 10 \\
\hline 86 & FRENCH WEST INDIES & 4.5810 & 10 \\
\hline 87 & CAMBODIA & 3.8673 & 10 \\
\hline 88 & BURMA & 3.7926 & 10 \\
\hline 89 & ALGERIA & 3.7331 & 10 \\
\hline 90 & PERU & 3.5180 & 10 \\
\hline 91 & SHARJAH & 3.4321 & 10 \\
\hline 92 & BAHAMA & 3.3659 & 10 \\
\hline 93 & ROMANIA & 3.1490 & 10 \\
\hline 94 & REPUBLIC OF LITHUANI & 3.0363 & 10 \\
\hline 95 & SOMALIA & 2.6751 & 10 \\
\hline 96 & URUGUAY & 2.5786 & 10 \\
\hline 97 & REPUBLIC OF KYRGYZST & 2.5262 & 10 \\
\hline 98 & BULGARIA & 2.3500 & 10 \\
\hline 99 & UGANDA & 2.3500 & 10 \\
\hline \multirow[t]{2}{*}{100} & LUXEMBURG & 2.0100 & 10 \\
\hline & TOTAL & 414.5798 & 2848 \\
\hline
\end{tabular}

\section{Emerging Variable}

\section{Adding New Commodities to the Export List}

In addition to the factors described above there is a fourth factor which will serve to support the first three. This factor has an overall impact on the diversification model in the sense that it works as a further remedy to balance out the existing export concentration and help in reducing the present export dependence on a very limited number of commodities. 
The projected volume that will emerge from the implementation of this support factor when added to the total export proceeds will provide the much needed additional export revenue from commodities which have not been given attention till date in spite of their substantial export potential. Related to this observation is the fact that the commodities that are being recommended for addition to the existing commodity list are such where considerable wastage is taking place at the point of production, a faulty storage and distribution mechanism is in practice and very low export prices are being fetched on a per tonne basis. The above commodities need to be exploited in view of their distinct attributes and the presence of an export surplus which far exceeds the domestic consumption requirements.

In order to diversify the export picture and to supplement the export earnings, exports of three major fruits whose total crop production is considerably in excess to Pakistan's domestic consumption requirements should be started on a priority basis. The fruits in order of their production tonnage, are citrus, mango and apple.

According to the statistics provided by the Ministry of Food Agriculture and Co-operatives and the Federal Bureau of Statistics, the production figures of citrus, mango and apple for the year 2000-2001 were 1866, 990 and 439 thousand tonnes respectively. The export value of these fruits has been stated in the statistics to stand at Rs.4575 million for 2000-2001. The total combined exports recorded in this year were of the order of 260 (000) tonnes. This means that existing exports are roughly seven per cent of total domestic production. In order to determine the actual demand potential for exports, an easier way to arrive at the tonnage figures will be to leave $25 \%$ of total production for wastage, $25 \%$ for domestic consumption and the balance $50 \%$ for exports. In this manner, the total tonnage available for export for the year 2008 works out at 1,157,000 tonnes carrying a value figure of US $\$ 0.5$ billion. This value represents a quantum leap in the total export value figure since only one commodity group, i.e., fresh fruits, if properly managed for exports, can add to the export revenue with a 0.5 billion dollar figure based on enhanced per tonne export price i.e. $\$ 350$ to $\$ 400$ per tonne. The fact that availability of a large export market will help enhance local production adding to the farmers' incomes and will also serve as a catalyst for growers of these fruits who then will be encouraged to use better crop management practices to increase per hectare yield. In future years, therefore, exports of these fruits will tend to become included in the major commodity export list and will provide a boost to export diversification reducing dependence on current export concentration in only five or six commodities Statistical Supplement (2004-2005). Actual export reported at 0.413 at million tones with a value figure of \$144.6 million 2005-2006 (News report Daily Jang July 24, 2008).

\section{2(a). Citrus Fruit}

Citrus is the most promising fruit for export since a special variety known as Kino which is a cross breed between two basic sweet and sour varieties, is grown in very large quantities in view of its unique taste and high juice content. This variety is already being exported to certain countries and has found consumer acceptance due to an additional factor of its long-term preservability at room temperature.

The production of citrus fruits has grown from 926,000 tonnes (1980-1981) to 1,866,000 tonnes (2001) Statistical Supplement (2004-2005) ultimately meaning a doubling of production in a period of 20 years and a $5 \%$ annual growth rate. Naturally, if exports are enlarged the total production can be expected to expand manifold because of abundant availability of water, fertilizers and pesticides.

Another factor that should be considered is the very low export price of Rs. 2000 per tonnes as has been reported in the above-mentioned publication. This price is the average obtained for the total mix of fruits being exported. Looking at the fact that citrus fetches a price of Rs.20,000 per tonne in the domestic market, the export price should be fixed at Rs.30,000 per tonne The low price currently prevalent in the export market reflects inadequacies in marketing and inability of the exporters to carry out successful image building. Certain factors that will affect the per hectare yield and the resultant total production are a function of proper transportation and infrastructure facilities at the right time and the right place. The wastage that is taking place must be drastically reduced, and proper packaging and labeling can help build an image and serve as a means to fetch a higher pertonne price. The fruit being produced in rural areas will need to be collected in pockets specially created for this purpose and to be packaged in export efficient containers after proper polishing and grading. The existing mechanisms for collection and marketing are totally inefficient resulting in a loss to producers and a shortage in supply to the domestic market at times of demand thus in turn creating an artificial price hike.

All the above suggestions can be implemented if a fruit collection, grading and export body is set up as a subsidiary to the highly powered Export Development Authority.

\section{2(b). Mango}

There are mango varieties that remain fresh under room temperature for sufficiently long periods. Only a few countries in the world produce this fruit, and Pakistan is conspicuous by the varieties of this fruit that it produces. This fruit is grown in Sindh and parts of Punjab and because of its exquisite taste is in great demand 
by the domestic population at large. The varieties grown through the use of semi culture have a special taste are larger in size and yield a greater quantity of the edible inner pulp.

The production figures between 1980-81 and 2000-2001 show a rise in production from 547,000 tonnes to 990,000 tonnes Statistical Supplement (2004-2005). Showing a doubling of production during the period under study.

The export prices of this fruit are also totally out of tune with the level that should actually be obtained. As in the case of citrus the average domestic price is Rs.20,000 per tonne. As such, in the case of mango too a price of Rs.30,000 per tonne should be aimed at and the market manipulated in a manner that this export price becomes actually achievable. Like citrus, mango also needs proper water, fertilizer and pesticides alongwith good farm-to-market mechanism to collect/store the fruit and its airfreight the collected quantities. In total, more than 400 varieties are grown. However, two most outstanding varieties which command a higher consumer price because of their inherent qualities need to be made the target for accelerated export.

\section{2(c). Apple}

Apple is a fruit which is recognized throughout the world as not only nutritious but as being endowed with ingredients that support human health in a befitting manner.

Pakistan has apple farming facilities in its hilly areas and the varieties that are produced are internationally acceptable. Three varieties have exquisite taste, flavour, texture and juice content. These varieties command a domestic price in the vicinity of Rs.30-40 per kg or Rs. 30000 to Rs. 40000 per tonne.

\section{Structural Transformation Variables}

The structural information variables are necessary ingredients into the model the other variables become effective in conjunction with this variable.

These factors have been labeled as reinforcement factors since at the present moment these institutions are not adequately equip to facilitate export development at an accelerated phase. The institutional development as per the outlined frameworks will serve as a catalyst for boosting exports and provide a mechanism whereby the diversification model will work in the focused direction.

The development of the proposed institutions will have a multiple effect in the sense that on the one hand they will serve as measures that will result in an enhanced capacity output of the commodities being currently exported and on the other they will help in the creation of export surplus for minor commodities too.

The minor commodities in particular need to be boosted to higher levels to achieve both volume and value increase in exports. The exports of these commodities need support in terms of availability of additional finance, export efforts by third party commitments and barter arrangements that will circumvent the need for additional capital. The institutions whose establishment has been recommended are already functioning in many other countries where they have markedly helped to enlarge the export picture. Pakistan has not yet paid attention to the role which such institutions can play to diversify and expand exports for obtaining greater market access.

\section{3(a). Direct Marketing}

In the ancient times when barter trade was in vogue buyers and sellers would need face to face to finalize the trade transactions today the modern practice due to fabulous development of transport and communication facilities direct trade in the presence of both the buyer and seller has become feasible. Now a days this practice has gained currency with the advent of world financial market and evaluation of hard convertible currency.

Naturally in this situation when one country deals with another it has to first consider its exchange parity and the amount of standard currencies like dollars, pounds or euros to be realized in such transactions. As such depending upon the exchange parities a country might dispose of a large quantum of its goods for a relatively small standard currency units gained in the process. This is more true and hurting for countries like Pakistan from the third world whose currencies are inconvertible when reviewed in terms of amount of standard currencies realized in trade transactions.

Direct marketing thus is considered an exchange viable and welcome mechanism for a country like Pakistan which is short on hard cash on the one hand and needs to spread the available miniscule cash over as large variety of imports as possible.

\section{3(b). Export Conglomerates}

Economies of scale in world competitiveness has a very crucial rule. World market operators compete among themselves with in a narrow margin of $0.5 \%$ of the average cost. Those companies who have established a well net organization for collection of exportable from many sources and packaging them to the exporters on a mass scale. The average size of exporters business in Pakistan is not quite large say the biggest exporters are 
able to process export order not more then 100 million dollars. At the same time the small exporter being in large number handle export less than 100 million dollars. In the circumstances Pakistan could promote through fiscal incentives nearly one dozen export companies who could cut their transaction cost substantially thereby enabling Pakistan to become competitive in world export prices in the relevant commodity categories.

Export conglomerates working as manufacturer's or export agent in the foreign markets if compensated properly can directly take title to the goods saving the exporter from the hassle of time lag between shipment and receipt of export proceeds. Additionally since the export conglomerates deals with a number of clients and multiple products simultaneously the margin allowed to such an agency does not represent an unwelcome burden to the exporter.

Thus the export conglomerates if properly employed and utilized by even small exporters in Pakistan could substantially help both in export enhancement and diversification.

\section{3(c). Establishment of Export/Import Bank}

For the expansion of agricultural sector, the Pakistan Government has established an Agricultural Development Bank with the specific objective of providing both macro and micro credit to large and small farmers to enhance the total agricultural output of the country.

This institution has played a key role in providing the necessary farm input in the form of credit to finance the acquisition of agricultural machinery, fertilizer, pesticides, and tube well etc. This action on the part of the government has played a dynamic and positive role in the expansion of crop outputs.

The export business needs a similar attention so that both large and small exporters are provided with the necessary financial assistance to meet the twin objective of export volume enhancement and diversification.

In this context, a number of countries have already established institutions which cater to the needs of export business either on a small or large scale. The institution being referred to here is an export/import bank which receives adequate funding from the government to meet short-and long-term credit needs of exporters there by providing assistance to increase the volume of inter-country trade specifically related to the country's export and import needs.

The assistance to be provided by such a bank, if established in Pakistan, will take various forms keeping in line with the following key assistance areas. In the first place, the Pakistan Government will need to direct the State Bank of Pakistan to provide substantial credit lines to this institution and keep on enlarging the credit base to cater to the continuously increasing financial requirements particularly with reference to export.

The specific measures which the export/import bank will focus attention on are given below:

(i) Grant of Loans on Subsidized Interest Rate

(ii) Relaxation in Debt-equity Ratio

(iii) Establishment of Branch Network

(iv) Specific Commodity Funding

\section{Fiscal \& Commercial Policy Variables}

The trade policies that are enacted from time play a vital role in the overall country-trade pattern. These policies directly result in attaining the twin objective of reducing trade deficit and improving the balance of payment position.

In relation to exports, particularly in the context of the aim of diversification, the Government of Pakistan needs to develop certain policies which have a bearing on this important aspect of the country's economy.

\section{4(a). Integrated Working of FBR, Ministry of Industries and Ministry of Commerce}

As has been pointed out earlier there is a lack of coordination between the body that determines duty and tax rates (CBR), the ministry which determines the direction of trade and commerce (Ministry of Commerce) and the ministry which is supposed to implements such directives (Ministry of Industries) creates road-block both in the value and direction of exports. The value is a function of duties and taxes whereas the directions depends upon policymaking and attainment of export surplus to attain these objectives.

The total effect of levies on exports should first be determined which will dictate the possible revenue generation from export, this should then be prioritized by the trade policy framework to be evolved and finally subjected to strict implementation by the Ministry of Industries resulting in capacity expansion, new investment, development of new industrial zones, training programs for skilled and unskilled labor among others.

\section{4(b). Facilitating New Industrial Enterprises}

The sole motivator for a flow of funds from the hands of entrepreneurs in the form of productive enterprise is the profit that comes about as a result of the efforts on the part of the entrepreneur to pool human 
and material resources and organize them in the form of a venture that promise both returns to the entrepreneur and benefits for the human resource thus employed.

Putting up a new industrial venture entails preparation of a proper feasibility to identify the potential industry for investment, obtaining governmental approval by providing support documents in addition to project feasibility papers, obtaining required land for putting up the proposed industrial venture, construction of the structure, erection and installation of machinery and equipment, getting sanction of adequate power and other utility services, and ensuring their actual availability on the proposed site. All these requirements cause a lot of hassle to the entrepreneur before he is actually able to attain a production start-up.

Since a number of functionaries are involved in fulfilling the basic requirements of a new industrial venture before it reaches an operational stage, the time lag that precedes each stage that is stated above needs to be shortened so that the proposed venture starts contributing its share to the nation's total productive output at an earliest time.

\section{4(c). Provision of Subsidy}

In the various interviews with exporters that were a part of this study, it was revealed that little incentives or concessions are granted by the government in spite of the fact that exports constitute a key area that deserves special attention of the government.

This is in contrast to the policies that other competing countries have put in force to encourage the export sector. These policy measures are in the form of rebates, tax concessions or tariff reduction in the imported component of exports.

The primary emphasis in this regard has been discussed below:

1. Concessional Export Credit Financing

2. Cash Compensatory Support

These have been discussed in detail below:

\section{(i) Concessional Export Credit Financing}

One of the popular objectives of export subsidy is to improve competition among exporters to increase the overall welfare effect. Concessional export financing is considered to be an effective tool. It is an active incentive that boosts export activities and has a positive impact on individual business performance. For this, it has to be targeted well and applied tactfully on the basis of a supply-and-demand analysis.

Export subsidy influences the market in two ways. First, the exporting sector expands and consequently its producer surplus is increased. Secondly, the government of the exporting country does not have to incure any real cost.

Concessional export financing is a vital tool used for facilitating the exports. This same technique is already in practice in several European countries like UK and France. In the words of Jepma and Rhoen in the book of International Trade, "Concessional export financing is a combination of Official Development Assistant (ODA), in the form of aid credits or grants, with officially supported export credits or regular commercial credits".

\section{(ii) Cash Compensatory Support}

Another very dominant export promotion measure is the cash subsidy scheme which in Pakistan is known as duty draw back. In its essence, its object is compensating the exporters for unrefunded taxes and duties on the manufacturing of exported goods. This scheme will be of special benefit to such capital scarce exporters who inspite of having up-to-date knowledge of export mechanism and expertise to tap additional export revenue are not able to expand their export operations which would be in the larger interest of Pakistan.

The scheme would involve.

1) Exemption from payment of taxes both on imports and exports.

2) Cash payment to cover high cost of transportation in case of agricultural exports.

3) Freight subsidy in full on a uniform basis on all export consignments.

For Pakistan, export is an issue that deserves special attention of the government. Export enhancement is dependent on the price and quality competition that Pakistan can offer.

In view of the escalating charges of utilities, the manufacturer cum exporter in Pakistan has suffered a setback in the sense that with the passage of time exports have tended to become uncompetitive. This needs remedial measures particularly in areas and sectors where provision of subsidy could enhance domestic output and create an effective surplus. 


\section{Conclusion}

Pakistan's economy was agrarian in content and style. Manufactured and semi manufactured goods were available to Pakistani consumers from the Indian provinces. We had to import necessary consumer and capital goods from other countries. Fortunately, Pakistan was able to pay for her imports from the export revenues of its raw cotton and jute. In fact there was balance of payment problem for Pakistan in the initial years. The export industry of Pakistan, on the other hand did not succeed in attracting new foreign purchases on a desired scale. In last two decades Pakistan under the influence of World Bank and IMF was obliged to adopt the policy of privatization, de-regulation, liberalization of trade, and financial marketing. On account of the political uncertainties, there was a flight of capital from Pakistan to the Western Block including USA and meanwhile the loan disbursement from World Bank and other donor agencies had almost dried up. All these factors severely affected the activities of export and the graph of export from Pakistan consistently showed decline. In order to ensure a sustainable position in the balance of payment, Pakistan must enhance her exports earnings and diversify her export trade for remarkable trade achievements. During this research study, we have developed a new strategy that would fulfill the requirements for sustaining the economy of Pakistan to a satisfactory and dignified level. In a nutshell, the suggested strategy model for export diversification aims at doubling the export earnings within a short period time. The task of export promotion has been sub divided by this multidirectional strategy. The analysis further establishes probability of export enhancement so that the chronic deficit in the balance of payment facing Pakistan since 1970, will be made good by a robust surplus in the balance of payment. The transformation of the economy of Pakistan reflecting the high export target will empower the country to follow independent economic development policy.

It may not be out of place to mention here that Pakistan is blessed with numerous huge natural resources that can safely guarantee a vibrant economy. Hopefully, in a period of 10 to 15 years, the adoption and compliance of the strategy for export diversification as suggested by the author, will bring fruit and Pakistan will be able to rise from the status of developing country and by successfully implementing the concomitant economic, social and legal reforms, Pakistan will rank among the highly industrialized and developed countries.

\section{References}

[1] Akbar, Muhammad, and Fatima, Zareen Naqvi. (2002, January 14-16).

Competitiveness Diversification of Pakistan's

[2] Alam, Babar Iqbal. (2006). Indo Pakistan Economic Relation Essential for survival. Management Accountant. Institute of Cost \& Management Accountants of Pakistan. p.15.

[3] Albaum Gerald, Standskov, Jesper and Duerr, Edwin. (1998). International Marketing and Export Management. Addison Wesley Longman Publishing Company. pp. 78-85.

[4] Annual Report. (2000 - 2001). State Bank of Pakistan. pp.13-16.

[5] Azam, Asim. (2004, October). Is Pakistan Export Competitive? The Dawn. p.17.

[6] Bhashyam, S. (1998). Export Promotion in India. New Delhi: Common Wealth Publishers. pp. 17-19.

[7] Economic Adviser's Wing. (2002). Economic Survey: 2001-2002. Finance Division. Islamabad: Government of Pakistan. pp.115125 .

[8] Economic Adviser's Wing. (2005). Statistical Supplement Economic Survey: 2004-2005. Finance Division. Islamabad: Government of Pakistan. p.139.

[9] Gay, and Diehl. (1984). Research Methods for Business and Management. New York: Maxwell Macmillan International. p.126.

[10] Hamza, Azam. (2004, November 8). Can Pakistan Follow Malaysia Export Model. The Dawn. p.4.

[11] Jempa, C.J., and Rhoen, A.P. (Eds.). (1996). International Trade. A business Perspective. New York: Addison Wesley Longman Publishing. pp. 161- 163.

[12] Naseeruddin, Muhammad. (1984, August 11-17). Export of Textiles and Quota System. Pakistan \& Gulf Economist. p.17.

[13] State Bank of Pakistan. (2000). Annual Report : 2000-2001 Published by State Bank of Pakistan: Author. pp. 13-16.

[14] Tarique, Ahmed. (1995, April 18-21). Export Earnings Instability in Pakistan. PIDE p.28.

[15] Bashyam, S. (1998). Export Promotion in India. New Delhi: Common Wealth Publishers. pp. 17-19.

[16] Chamber of Commerce and Industry. (2002). UR Agreements of GAIT an Anti-Dumping and Countervailing Measures. Karachi: Research and Economic Development Cell.

[17] Export Promotion Bureau. (2003, November). Pakistan Export and Investment Guide. Karachi: Published in collaboration with Export Promotion Bureau, Government of Pakistan. pp. 90-200.

[18] Glassburner, Dr. Bruce. (1964, Winter). The Pakistan Development Review. Quarterly Journal of the Pakistan Institute of Development Economics.

[19] Huges, Kirsty. (1986). Export and Technology. Cambridge: Cambridge University Press. Noonan, Chris. (1996). The CIM Handbook of Export Marketing. Published on behalf of the Chartered Institute of Marketing.

Onkvisit, Sak, and Shaw, John J. (1997). International Marketing. New Jersey: Prentice Hall pp. 81-163.

[21] Panitchpakdi, Supachai and Clifford, Mark L. (2002). China and the WTO. Singapore: Saikwah Press. pp. $180-191$

[22] Paramashivaish, P., and Agadi, Dr. Ramesh. (2003, May). Export Policy-Promotion and Performance. Management Accountant. Karachi: Institute of Cost and Management Accountants of Pakistan.

[23] Yeates, Mawrice H. (1968). An Introduction to Quantitative Analysis in Economic Geography. New York: Book Company. pp. 33-37.

[24] Federal Bureau of Statistics (2001) Foreign Trade Statistics of Pakistan Export \& Re -Exports published by the Manager of Publications Karachi Government of Pakistan pp 20-22 
TABLE A

Total World Imports Selected Countries

\section{LEATHER}

\begin{tabular}{|l|c|}
\hline \multicolumn{1}{|c|}{ Country } & $\begin{array}{c}\text { Value in Million } \\
\text { (2005) }\end{array}$ \\
\hline China & $\$ 58.35$ \\
\hline Hong Kong & 54.77 \\
\hline Italy & 35.85 \\
\hline Romania & 12.93 \\
\hline Germany & 10.91 \\
\hline Spain & 8.98 \\
\hline Poland & 8.23 \\
\hline Republic of Korea & 7.23 \\
\hline France & 6.46 \\
\hline Viet Nam & - \\
\hline Portugal & 5.63 \\
\hline Thailand & 5.55 \\
\hline Taiwan & 4.2 \\
\hline United Kingdom & 3.67 \\
\hline Hungary & 3.6 \\
\hline Japan & 3.03 \\
\hline Turkey & 3 \\
\hline Canada & 2.92 \\
\hline Netherlands & 2.28 \\
\hline Malaysia & 2.05 \\
\hline Brazil & 2.01 \\
\hline Bulgaria & 1.9 \\
\hline Austria & 1.61 \\
\hline Belgium & 1.6 \\
\hline Indonesia & 1.19 \\
\hline Australia & 1.42 \\
\hline Singapore & 1.12 \\
\hline Denmark & 1.03 \\
\hline Switzerland & 1 \\
\hline Philippines & 0.85 \\
\hline Norway & \\
\hline Greece & \\
\hline Sri Lanka & \\
\hline
\end{tabular}

Source :

http://www.intracen.org/tradstat/sitc3-3d
TABLE B

Total World Imports Selected Countries

\section{FOOTWEAR}

\begin{tabular}{|l|c|}
\hline \multicolumn{1}{|c|}{ Country } & $\begin{array}{c}\text { Value in Million } \\
(\mathbf{2 0 0 5})\end{array}$ \\
\hline USA & \$15.11 \\
\hline Hong Kong & 89.74 \\
\hline Germany & 86.32 \\
\hline United Kingdom & 79.47 \\
\hline France & 78.94 \\
\hline Italy & 74.8 \\
\hline Japan & 59.71 \\
\hline Belgium & 33.53 \\
\hline Spain & 30.91 \\
\hline Netherlands & 30.25 \\
\hline Canada & 22.78 \\
\hline Austria & 18.34 \\
\hline Switzerland & 14.47 \\
\hline Australia & 13.37 \\
\hline Denmark & 12.15 \\
\hline Republic of Korea & 11.18 \\
\hline Sweden & 9.6 \\
\hline China & 9.03 \\
\hline South Africa & 8.12 \\
\hline Portugal & 8.06 \\
\hline Romania & 7.17 \\
\hline Poland & 7.15 \\
\hline Turkey & 6.88 \\
\hline Ireland & 6.69 \\
\hline Taiwan & 6.64 \\
\hline Hungary & 5.38 \\
\hline Chile & 5.11 \\
\hline Viet Nam & - \\
\hline Saudi Arabia & 4.29 \\
\hline UAE & - \\
\hline Colombia & 2.34 \\
\hline Serbia and Montenegro & - \\
\hline Malaysia & 0.99 \\
\hline Kuwait & \\
\hline Indonesia & \\
\hline Philippines & \\
\hline & \\
\hline
\end{tabular}

Source : http://www.intracen.org/tradstat/sitc3-3d 
TABLE C

Total World Imports Selected Countries

INSTRUMENTS \& APPLIANCES FOR MEDICAL, SURGICAL DENTAL OR VETERINARY

\begin{tabular}{|l|c|}
\hline \multicolumn{1}{|c|}{ Country } & $\begin{array}{c}\text { Value in Million } \\
\text { (2005) }\end{array}$ \\
\hline Netherlands & $\$ 63.52$ \\
\hline United Kingdom & 62.85 \\
\hline Germany & 60.74 \\
\hline Japan & 58.98 \\
\hline France & 45.09 \\
\hline Belgium & 38.93 \\
\hline Italy & 36.74 \\
\hline Canada & 27.9 \\
\hline Spain & 21.57 \\
\hline Australia & 15.84 \\
\hline China & 15.08 \\
\hline Hong Kong & 14.2 \\
\hline Switzerland & 13.58 \\
\hline Republic of Korea & 11.51 \\
\hline Austria & 10.09 \\
\hline Sweden & 9.92 \\
\hline Turkey & 9.37 \\
\hline Ireland & 8.48 \\
\hline India & 7.73 \\
\hline Greece & 6.47 \\
\hline Poland & 5.94 \\
\hline Saudi Arabia & 5.07 \\
\hline Malaysia & 4.66 \\
\hline Portugal & 4.59 \\
\hline Brazil & 4.18 \\
\hline Thailand & 3.05 \\
\hline Hungary & 2.43 \\
\hline Romania & 1.44 \\
\hline Philippines & 1.08 \\
\hline Viet Nam & - \\
\hline Kenya & - \\
\hline UAE & - \\
\hline Nigeria & - \\
\hline & \\
\hline & \\
\hline
\end{tabular}

\begin{tabular}{|l|c|}
\hline \multicolumn{1}{|c|}{ Country } & $\begin{array}{c}\text { Value in Million } \\
(\mathbf{2 0 0 5})\end{array}$ \\
\hline Hong Kong & $\$ 45.45$ \\
\hline Mexico & 15.42 \\
\hline France & 6.5 \\
\hline Sri Lanka & 6.47 \\
\hline Italy & 6.23 \\
\hline Thailand & 5.97 \\
\hline Cambodia & - \\
\hline Philippines & 4.83 \\
\hline Poland & 4.16 \\
\hline Canada & 4.1 \\
\hline Morocco & 3.42 \\
\hline Romania & 3.37 \\
\hline Belgium & 2.91 \\
\hline Malaysia & 2.91 \\
\hline UAE & - \\
\hline Spain & 2.86 \\
\hline Singapore & 2.58 \\
\hline Hungary & 2.15 \\
\hline Portugal & 1.75 \\
\hline Japan & 1.69 \\
\hline Austria & 1.6 \\
\hline Australia & 1.29 \\
\hline Republic of Korea & 1.27 \\
\hline Indonesia & 1.16 \\
\hline Switzerland & 1.13 \\
\hline Ireland & 1.06 \\
\hline Greece & 1.05 \\
\hline Sweden & 0.54 \\
\hline Saudi Arabia & 0.15 \\
\hline
\end{tabular}

Source :

http://www.intracen.org/tradstat/sitc3-3d

TABLE D

Total World Imports Selected Countries
KNITTED FABRICS

Source : $\underline{\text { http://www.intracen.org/tradstat/sitc3-3d }}$ 
TABLE E

Total World Imports Selected Countries

MADE-UP ARTICLES

\begin{tabular}{|c|c|}
\hline Country & $\begin{array}{l}\text { Value in Million } \\
\qquad(2005)\end{array}$ \\
\hline Germany & $\$ 40.41$ \\
\hline United Kingdom & 29.35 \\
\hline France & 28.84 \\
\hline Canada & 14.19 \\
\hline Spain & 13.58 \\
\hline Italy & 13.28 \\
\hline Belgium & 12.37 \\
\hline Netherlands & 11.62 \\
\hline Australia & 8.95 \\
\hline Switzerland & 6.95 \\
\hline Sweden & 6.87 \\
\hline Austria & 6.53 \\
\hline Hong Kong & 6.46 \\
\hline Denmark & 4.68 \\
\hline Poland & 4.35 \\
\hline Republic of Korea & 3.84 \\
\hline Saudi Arabia & 3.51 \\
\hline Greece & 3.39 \\
\hline Ireland & 3.15 \\
\hline New Zealand & 2.49 \\
\hline Portugal & 1.98 \\
\hline Hungary & 1.37 \\
\hline UAE & - \\
\hline Argentina & 1.14 \\
\hline Thailand & 1.07 \\
\hline Turkey & 1.06 \\
\hline Malaysia & 0.97 \\
\hline Brazil & 0.52 \\
\hline Philippines & 0.22 \\
\hline Indonesia & 0.2 \\
\hline Sri Lanka & 0.12 \\
\hline
\end{tabular}

Source :

http://www.intracen.org/tradstat/sitc3-3d
TABLE F

Total World Imports Selected Countries

TEXTILE FABRICS, WOVEN

\begin{tabular}{|c|c|}
\hline Country & $\begin{array}{l}\text { Value in Million } \\
\qquad(2005)\end{array}$ \\
\hline Italy & $\$ 8.94$ \\
\hline France & 7.01 \\
\hline Romania & 5.73 \\
\hline Turkey & 5.63 \\
\hline Spain & 5.45 \\
\hline Poland & 3.83 \\
\hline Belgium & 2.39 \\
\hline Mexico & 2.35 \\
\hline Denmark & 2.32 \\
\hline Austria & 2.14 \\
\hline Switzerland & 2.07 \\
\hline Portugal & 2.02 \\
\hline Netherlands & 1.6 \\
\hline Thailand & 1.3 \\
\hline Australia & 1.23 \\
\hline Greece & 1 \\
\hline Sweden & 0.91 \\
\hline Philippines & 0.76 \\
\hline Singapore & 0.72 \\
\hline Malaysia & 0.45 \\
\hline New Zealand & 0.43 \\
\hline Sri Lanka & 0.38 \\
\hline Indonesia & 0.21 \\
\hline Algeria & - \\
\hline
\end{tabular}

Source :

http://www.intracen.org/tradstat/sitc3-3d 
TABLE G

Total World Imports Selected Countries

TEXTILE YARN

\begin{tabular}{|l|c|}
\hline \multicolumn{1}{|c|}{ Country } & Value in Million(2005) \\
\hline China & $\$ 69.98$ \\
\hline Hong Kong & 67.60 \\
\hline USA & 44.94 \\
\hline Italy & 41.57 \\
\hline Germany & 36.02 \\
\hline Turkey & 25.50 \\
\hline France & 25.27 \\
\hline Republic of Korea & 24.81 \\
\hline Belgium & 19.19 \\
\hline United Kingdom & 18.18 \\
\hline Japan & 18.02 \\
\hline Spain & 15.16 \\
\hline Netherlands & 12.64 \\
\hline Canada & 11.94 \\
\hline Mexico & 9.67 \\
\hline Portugal & 9.55 \\
\hline Brazil & 9.14 \\
\hline Poland & 8.41 \\
\hline India & 8.36 \\
\hline Czech Republic & 8.30 \\
\hline Taiwan & 7.24 \\
\hline Thailand & 6.99 \\
\hline Bangladesh & - \\
\hline Austria & 5.36 \\
\hline Australia & 5.11 \\
\hline Viet Nam & - \\
\hline Malaysia & 3.81 \\
\hline Philippines & 3.47 \\
\hline Denmark & 3.38 \\
\hline Greece & 3.19 \\
\hline Hungary & 2.69 \\
\hline Sweden & 2.71 \\
\hline Morocco & 2.57 \\
\hline Singapore & 1.49 \\
\hline Ireland & -16 \\
\hline Norway & \\
\hline Kenya & - \\
\hline Brunei Darussalam & \\
\hline
\end{tabular}

Source : http://www.intracen.org/tradstat/sitc3-3d 